\title{
Gambaran Anemia pada Subjek Penyakit Ginjal Kronik Stadium 4 dan 5 di Poliklinik Ginjal-Hipertensi RSUP Prof. Dr. R. D. Kandou
}

\author{
Yordhan Tamsil, ${ }^{1}$ Emma Sy. Moeis, ${ }^{2}$ Frans Wantania ${ }^{2}$
}

\author{
${ }^{1}$ Program Studi Pendidikan Dokter Fakultas Kedokteran Universitas Sam Ratulangi Manado \\ ${ }^{2}$ Bagian Ilmu Penyakit Dalam Fakultas Kedokteran Universitas Sam Ratulangi Manado \\ Email: yordhantamsil@gmail.com
}

\begin{abstract}
Anemia is a complication of chronic kidney disease (CKD) that often occurs. Moreover, it can occur earlier than other complications of CKD in almost all patients with late stage kidney disease. This study was aimed to obtain the profile of anemia in subjects with stage 4 and 5 of chronic kidney disease. This was a retrospective and descriptive study using medical records of patients with CKD associated with anemia for two years. The results showed that of 428 CKD patients, 131 suffered from anemia (30.60\%). The majority of patients were female (54.19\%), age range 60-69 years (44.27\%), non-dialysis stage 5 of CKD patients $(74.04 \%)$, had sufficient iron status (79.38\%). However, $15,26 \%$ of the 131 patients got blood transfusion therapy. In conclusion, the majority of CKD patients were stage $5 \mathrm{ND}$, female, age range of 60-69 years, had sufficient iron status, and were not treated with blood transfusion.
\end{abstract}

Keywords: chronic kidney disease, anemia

\begin{abstract}
Abstrak: Anemia merupakan komplikasi penyakit ginjal kronik (PGK) yang sering terjadi, bahkan dapat terjadi lebih awal dibandingkan komplikasi PGK lainnya dan hampir pada semua pasien penyakit ginjal tahap akhir. Penelitian ini bertujuan untuk mengetahui gambaran anemia pada subyek penyakit ginjal kronik stadium 4 dan 5 di Poliklinik Ginjal-Hipertensi RSUP Prof. Dr. R. D. Kandou. Jenis penelitian ialah metode deskriptif retroskpektif dengan mengunakan data rekam medik pasien PGK dengan anemia selama dua tahun. Hasil penelitian memperlihatkan dari 428 pasien PGK didapatkan 131 pasien dengan anemia pada PGK $(30,60 \%)$. Mayoritas pasien ialah jenis kelamin perempuan $(54,19 \%)$, usia 60-69 tahun $(44,27 \%)$, dan PGK derajat 5 non-dialisis $(74,04 \%)$, memiliki status besi cukup $(79,38 \%)$. Terdapat $15,26 \%$ dari pasien yang mendapatkan terapi transfusi darah. Simpulan penelitian ini ialah pasien terbanyak dengan derajat $5 \mathrm{ND}$, jenis kelamin perempuan, rentang usia 60-69 tahun, dengan status besi cukup, dan tidak mendapat terapi transfusi darah.
\end{abstract}

Kata kunci: penyakit ginjal kronik, anemia

\section{PENDAHULUAN}

Penyakit ginjal kronik (PGK) merupakan abnormalitas fungsi dan struktur ginjal, dimana laju filtrasi glomerulus (LFG) <60 $\mathrm{ml} / \mathrm{menit}$ per $1,73 \mathrm{~m}^{2}$ dan terjadi kerusakan ginjal yang sudah berlangsung lebih dari 3 bulan. Kerusakan ginjal ini berupa albuminuria yang ditandai dengan laju ekskresi albumin $\geq 30 \mathrm{mg} / 24$ jam atau rasio albumin kreatinin urin $\geq 30 \mathrm{mg} / \mathrm{mmol}$, sedimen urin abnormal, gangguan elektrolit dan juga kelainan lainnya yang disebabkan oleh gangguan tubular ginjal, histologi yang abnormal, struktur abnormal yang ditemukan melalui pencitraan, atau riwayat transplantasi ginjal. PGK juga merupakan proses penurunan fungsi ginjal yang progresif, dan pada umumnya berakhir dengan gagal ginjal.

Anemia adalah suatu keadaan dimana 
menurunnya kadar hemoglobin $(\mathrm{Hb})$ dan jumlah eritrosit. Seorang pasisen dinyatakan anemia apabila $\mathrm{Hb}<13 \mathrm{~g} / \mathrm{dl}$ pada lakilaki dan $\mathrm{Hb}<12 \mathrm{~g} / \mathrm{dl}$ pada perempuan., ${ }^{2,3}$ Gejala umum anemia antara lain cepat lelah, takikardi, takipneu pada latihan fisik, dan palpitasi. ${ }^{4}$

Anemia pada pasien penyakit ginjal kronik terutama disebabkan oleh defisiensi eritropoietin. Ginjal merupakan sumber utama produksi eritropoietin dan fungsi ginjal menolak untuk memroduksi eritropoietin dengan seimbang, sebagai hasilnya, terdapat kecenderungan hubungan linear antara kadar $\mathrm{Hb}$ dan LFG pada pasien dengan PGK. $^{2}$ Sel-sel peritubular yang menghasilkan eritropoietin rusak sebagian atau seluruhnya seiring dengan progresifnya penyakit ginjal. Defisiensi eritropoietin pada PGK dapat berespon terhadap penurunan fungsi glomerulus. ${ }^{5,6}$ Hal-hal lain yang ikut berperan dalam terjadinya anemia ialah defisiensi besi, kehilangan darah (perdarahan saluran cerna, hematuria), masa hidup eritrosit yang pendek akibat terjadinya hemolisis, defisiensi asam folat, penekanan sumsum tulang oleh substansi uremik, dan proses inflamasi akut maupun kronik. ${ }^{7}$ Banyak pasien PGK juga mendapatkan infeksi dalam kaitannya dengan kondisi-kondisi lain seperti arthritis. Infeksi ini dapat menyebabkan peningkatan kadar hepcidin, yang dapat menurunkan absopsi besi dari traktus gastrointestinal dan merusak pelepasan besi dari sumsum tulang. Keadaan infeksi ini juga tidak hanya menurunkan produksi dari eritropoietin penyebab anemia, tetapi juga komorbiditas, terutama pada pasien PGK. ${ }^{2}$

Penyebab umum dari anemia yaitu defisiensi besi dan juga pada pasien dengan PGK dengan hasil anemia defisiensi besi absolut. Anemia defisiensi dapat terjadi ketika defisiensi besi cukup berat untuk mengurangi eritropoiesis dan menyebabkan pengembangan anemia. Defisiensi besi absolut dapat didefinisikan sebagai penurunan keseluruhan isi besi tubuh. Pada PGK, baik anemia defisiensi besi absolut dan anemia defisiensi besi fungsional umum didapatkan. Defisiensi besi fungsio- nal yaitu keadaan dimana isi total besi tubuh normal atau bahkan meningkat, tetapi besi terkunci dan tidak tersedia untuk produksi sel darah merah. Anemia defisiensi besi absolut didefinisikan sebagai kehabisan cadangan jaringan besi. Memonitor penatalaksanaan eritropoietin pada status besi pasien penting untuk mendeteksi defisiensi besi dan mencegah efek kurang baik pada pengobatan. ${ }^{8}$

Angka kejadian anemia meningkat pada stadium yang berbeda dan nilai $\mathrm{Hb}$ menunjukkan bahwa terapi dengan eritropoietin diperlukan. Terdapat perbedaan antara pola anemia pada laki-laki dan perempuan, yaitu jenis kelamin perempuan lebih menjadi faktor risiko terhadap anemia pada pasien PGK. ${ }^{9}$

\section{METODE PENELITIAN}

Penelitian ini dilaksanakan di Poliklinik Ginjal-Hipertensi RSUP Prof. Dr. R. D. Kandou Manado pada bulan SeptemberOktober 2019. Jenis penelitian ialah deskriptif, berdasarkan data sekunder dari catatan rekam medis pasien dengan PGK periode tahun 2017-2018 di Poliklinik Ginjal-Hipertensi RSUP Prof. Dr. R. D. Kandou.

Populasi penelitian ialah semua subjek PGK yang rawat jalan di poliklinik GinjalHipertensi RSUP Prof. Dr. R. D. Kandou. Subjek penelitian ialah populasi penelitian yang memenuhi syarat kriteria inklusi dan eksklusi, yaitu semua pasien PGK stadium 4 dan 5 ND rawat jalan di poliklinik GinjalHipertensi RSUP Prof. Dr. R. D. Kandou yang berjumlah 131 pasien.

Penelitian ini telah mendapat persetujuan dari Komisi Etik Penelitian Kesehatan RSUP Prof. Dr. R. D. Kandou Manado, dengan nomor keterangan layak etik yaitu No. 054/EC/KEPK-KANDOU/X/2019.

\section{HASIL PENELITIAN}

Penelitian ini dilakukan di Instalasi Rekam Medis dan poliklinik ginjalhipertensi RSUP Prof. Dr. R. D. Kandou Manado periode Januari 2017-Desember 2018 dengan mengambil data pasien PGK. Dari hasil penelitian, didapatkan jumlah 
pasien yang masuk dalam kriteria inklusi ialah 131 pasien $(30,60 \%)$ dari total 428 pasien yang terdiagnosis PGK, terdiri dari 33 orang $(25,19 \%)$ PGK derajat 4 dan 98 orang $(74,80 \%)$ PGK derajat 5 ND.

Tabel 1 memperlihatkan rerata usia pasien PGK derajat 4 ialah 60,62 tahun dan PGK derajat 5 ND ialah 61,06 tahun. Hemoglobin $(\mathrm{Hb})$ pasien PGK derajat 4 ialah $11,51 \mathrm{~g} / \mathrm{dl}$ dan pada PGK derajat 5 ND ialah 8,72 g/dl. Serum iron (SI) pada PGK derajat 4 ialah 67,09 dan pada PGK derajat 5 ND ialah 80,66. Total iron binding capacity (TIBC) pada PGK derajat 4 ialah 223,67 dan pada PGK derajat 5 ND ialah 214,51. Saturasi transferin (ST) pada PGK derajat 4 ialah 35,43 dan pada PGK derajat 5 ND ialah 41,68. Feritin serum (FS) pada PGK derajat 4 ialah 511,9 dan pada PGK derajat 5 ND ialah 648,02.

Tabel 2 memperlihatkan bahwa berdasarkan hasil penelitian terdapat 131 pasien yang menderita anemia pada PGK. Dari 131 pasien tersebut, 33 orang $(25,19 \%)$ diantaranya merupakan pasien anemia dengan PGK derajat 4, sedangkan 98 orang $(74,80 \%)$ lainnya merupakan anemia dengan PGK derajat 5 ND.

Tabel 3 memperlihatkan bahwa berdasarkan hasil penelitian anemia pada subjek
PGK derajat 4 didapatkan pasien dengan kelompok usia mayoritas terjadi pada 60-69 tahun yaitu sebanyak 16 orang $(51,61 \%)$.

Tabel 4 memperlihatkan bahwa berdasarkan hasil penelitian anemia pada subjek PGK derajat 5 ND didapatkan pasien dengan kelompok usia mayoritas terjadi pada 60-69 tahun yaitu sebanyak 42 orang $(42,85 \%)$.

Tabel 5 memperlihatkan bahwa dari 131 pasien anemia pada PGK yang memiliki status besi cukup pada PGK derajat 4 sebanyak 23 orang $(17,55 \%)$ sedangkan pada PGK derajat 5 ND sebanyak 80 orang $(61,06 \%)$. Pasien dengan defisiensi besi fungsional pada PGK derajat 4 dan 5 ND tidak ada. Pasien dengan defisiensi besi absolut pada PGK derajat 4 sebanyak 3 orang $(2,29 \%)$ sedangkan pasien dengan PGK derajat 5 ND sebanyak 2 orang $(1,52 \%)$; sisanya 23 orang $(17,55 \%)$ tidak masuk dalam kriteria.

Tabel 6 memperlihatkan bahwa dari 131 pasien anemia pada PGK yang mendapatkan terapi transfusi darah pada PGK derajat 4 sebanyak 1 orang $(0,76 \%)$ sedangkan pada pasien PGK derajat 5 ND yang mendapat terapi transfusi darah sebanyak 19 orang $(14,50 \%)$.

Tabel 1. Karakteristik sampel penelitian

\begin{tabular}{ccccccccc}
\hline Variabel & \multicolumn{4}{c}{ PGK-4 } & \multicolumn{4}{c}{ PGK-5 ND } \\
& Min & Max & Rerata & $\mathrm{N}$ & Min & Max & Rerata & $\mathrm{N}$ \\
\hline Usia (tahun) & 47 & 76 & 60,62 & & 33 & 84 & 61,06 & \\
Hb $(\mathrm{g} / \mathrm{dl})$ & 5,30 & 12,3 & 11,51 & & 3,40 & 12 & 8,72 & \\
SI $(\mu \mathrm{g} / \mathrm{dl})$ & 12 & 207 & 67,09 & 33 & 14 & 213 & 80,66 & \\
TIBC $(\mu \mathrm{g} / \mathrm{dl})$ & 123 & 386 & 223,67 & & 47 & 327 & 214,51 & 98 \\
ST $(\%)$ & 6 & 95 & 35,43 & & 10 & 100 & 41,68 & \\
FS $(\mu \mathrm{g} / \mathrm{dl})$ & 8,726 & 1250 & 511,9 & & 42,56 & 2000 & 648,02 & \\
\hline
\end{tabular}

Tabel 2. Prevalensi anemia pada subjek PGK 4 dan 5 ND

\begin{tabular}{cccccc}
\hline Hb $(\mathbf{g} / \mathbf{d l})$ & \multicolumn{2}{c}{ PGK 4 } & \multicolumn{2}{c}{ PGK 5 ND } & Total \\
& $\mathrm{N}$ & $\%$ & $\mathrm{~N}$ & $\%$ & $\mathrm{~N}$ \\
\hline $9-12$ & 17 & 12,97 & 53 & 40,45 & 70 \\
$7-9$ & 13 & 9,92 & 30 & 22,90 & 43 \\
$<7$ & 3 & 2,29 & 15 & 11,45 & 18 \\
Total & 33 & 25,19 & 98 & 74,80 & 131 \\
\hline
\end{tabular}


Tabel 3. Prevalensi anemia berdasarkan usia dan jenis kelamin pada subjek PGK derajat 4

\begin{tabular}{|c|c|c|c|c|c|c|c|}
\hline \multirow{3}{*}{$\begin{array}{r}\text { Kelompok } \\
\text { usia (tahun) }\end{array}$} & \multicolumn{6}{|c|}{ Hb } & \multirow{3}{*}{ Total } \\
\hline & \multicolumn{3}{|c|}{ Laki-laki } & \multicolumn{3}{|c|}{ Perempuan } & \\
\hline & $9-13$ & $7-9$ & $<7$ & $9-12$ & $7-9$ & $<7$ & \\
\hline $20-29$ & 0 & 0 & 0 & 0 & 0 & 0 & 0 \\
\hline $30-39$ & 0 & 0 & 0 & 0 & 0 & 0 & 0 \\
\hline $40-49$ & 1 & 0 & 0 & 1 & 1 & 1 & 4 \\
\hline $50-59$ & 4 & 3 & 0 & 1 & 2 & 0 & 10 \\
\hline $60-69$ & 6 & 2 & 2 & 1 & 5 & 0 & 16 \\
\hline$>70$ & 0 & 0 & 0 & 3 & 0 & 0 & 3 \\
\hline Total & 11 & 5 & 2 & 6 & 8 & 1 & 33 \\
\hline
\end{tabular}

Tabel 4. Prevalensi anemia berdasarkan umur dan jenis kelamin pada subjek PGK derajat 5 ND

\begin{tabular}{cccccccc}
\hline $\begin{array}{c}\text { Kelompok usia } \\
\text { (tahun) }\end{array}$ & \multicolumn{9}{c}{ Laki-laki } & \multicolumn{5}{c}{ Perempuan } & Total \\
& $9-13$ & $7-9$ & $<7$ & $9-12$ & $7-9$ & $<7$ & \\
\hline $20-29$ & 0 & 0 & 0 & 0 & 0 & 0 & 0 \\
$30-39$ & 0 & 1 & 0 & 2 & 0 & 0 & 3 \\
$40-49$ & 4 & 0 & 4 & 3 & 2 & 0 & 13 \\
$50-59$ & 3 & 5 & 2 & 4 & 6 & 1 & 21 \\
$60-69$ & 11 & 7 & 2 & 12 & 7 & 3 & 42 \\
$>70$ & 3 & 1 & 0 & 10 & 3 & 2 & 19 \\
Total & 21 & 14 & 8 & 31 & 18 & 6 & 98 \\
\hline
\end{tabular}

Tabel 5. Prevalensi status besi pada subjek PGK 4 dan 5 ND

\begin{tabular}{|c|c|c|c|c|c|}
\hline \multirow[t]{2}{*}{ Status besi } & \multicolumn{2}{|c|}{ PGK-4 } & \multicolumn{2}{|c|}{ PGK-5 ND } & \multirow[t]{2}{*}{ Total } \\
\hline & $\mathrm{N}$ & $\%$ & $\mathrm{~N}$ & $\%$ & \\
\hline $\begin{array}{c}\text { Cukup } \\
(\mathrm{ST}>20, \mathrm{FS}>100)\end{array}$ & 23 & 17,55 & 80 & 61,06 & 103 \\
\hline $\begin{array}{l}\text { Defisiensi besi fungsional } \\
\quad(\mathrm{ST}>20, \mathrm{FS}<100)\end{array}$ & 0 & 0 & 0 & 0 & 0 \\
\hline $\begin{array}{l}\text { Defisiensi besi absolut } \\
\quad(S T<20, F S<100)\end{array}$ & 3 & 2,29 & 2 & 1,52 & 5 \\
\hline Total & 26 & 19,84 & 82 & 62,59 & 108 \\
\hline
\end{tabular}

Tabel 6. Prevalensi terapi transfusi darah pada subjek PGK 4 dan 5 ND

\begin{tabular}{cccccccccc}
\hline & \multicolumn{4}{c}{ PGK 4 } & \multicolumn{7}{c}{ PGK 5 ND } \\
Hb (g/dl) & \multicolumn{1}{c}{ Transfusi (+) } & Transfusi (-) & \multicolumn{2}{c}{ Transfusi (+) } & Transfusi (-) & \multirow{2}{*}{ Total } \\
& $\mathrm{N}$ & $\%$ & $\mathrm{~N}$ & $\%$ & $\mathrm{~N}$ & $\%$ & $\mathrm{~N}$ & $\%$ & \\
\hline $9-12$ & 0 & 0 & 17 & 12,97 & 7 & 5,34 & 46 & 35,11 & 70 \\
$7-9$ & 0 & 0 & 13 & 9,92 & 6 & 4,58 & 24 & 18,32 & 43 \\
$<7$ & 1 & 0,76 & 2 & 1,52 & 6 & 4,58 & 9 & 6,87 & 18 \\
Total & 1 & 0,76 & 32 & 24,42 & 19 & 14,50 & 79 & 60,30 & 131 \\
\hline
\end{tabular}

\section{BAHASAN}

Tujuan penelitian ini ialah untuk mengetahui gambaran anemia pada subjek PGK stadium 4 dan 5. Data penelitian ini didapat dari data rekam medis pasien PGK di RSUP Prof. Dr. R. D. Kandou Manado periode Januari 2017-Desember 2018, dengan pasien yang terdiagnosis PGK berjumlah 131 dari total 428 pasien PGK yang masuk dalam kriteria inklusi.

Berdasarkan hasil penelitian, prevalensi karakteristik subyek pada PGK derajat 
4 dan 5 ND memiliki usia rata-rata 60-62 tahun. Hal ini menandakan banyak pasien PGK terjadi pada usia lanjut karena LFG menurun seiring bertambahnya usia. ${ }^{10}$ Nilai $\mathrm{Hb}$ rerata PGK derajat 4 yaitu 11,51 g/dl dan $\mathrm{Hb}$ rerata pada PGK 5 ND yaitu 8,72 $\mathrm{g} / \mathrm{dl}$. Terlihat bahwa kedua derajat PGK mengalami penurunan $\mathrm{Hb}$, akan tetapi $\mathrm{Hb}$ rerata pada PGK derajat 5 ND lebih rendah daripada PGK derajat 4. Hal ini dikarenakan semakin menurunnya LFG atau semakin beratnya PGK maka produksi eritropoietin akan berkurang. ${ }^{11}$ Kadar SI rerata pada PGK derajat 4 dan 5 ND masih dalam rentang normal, yaitu nilai normal SI berkisar antara 55-160 $\mu \mathrm{g} / \mathrm{dl}$ pada laki-laki dan 40-155 $\mu \mathrm{g} / \mathrm{dl}$ pada perempuan. Kadar TIBC rerata pada PGK derajat 4 dan 5 ND kedunya mengalami penurunan; hal ini dikarenakan terjadi peningkatan feritin dan dapat terjadi pada anemia penyakit kronis inflamasi. $^{12}$ Kadar ST rerata pada PGK derajat 4 dan 5 ND masih dalam rentang normal yaitu rentang normal ST adalah 20$50 \%$. Kadar FS rata-rata pada PGK derajat 4 dan 5 ND keduanya mengalami kenaikan dari kadar normal yaitu FS $>100$. Hal ini menunjukan cadangan besi tubuh tinggi. FS merupakan protein fase akut yang meningkat pada keadaan infeksi-inflamasi. Hal ini terjadi karena hambatan pelepasan besi dari cadangan (cell's storape) ke sirkulasi (inflamatory iron block).

Berdasarkan hasil penelitian, prevalensi pasien PGK derajat 5 ND lebih banyak yaitu 98 orang $(74,80 \%)$. Penelitian yang dilakukan Hidayat et al ${ }^{13}$ pada PGK juga mendapatkan bahwa pasien dengan derajat 5 non-dialisis lebih banyak terjadi $(85,10 \%)$. Sejalan juga dengan penelitian yang dilakukan Prodjosudjadi et $\mathrm{al}^{14}$ yang menyebutkan bahwa mayoritas pasien PGK terjadi pada derajat lanjut atau derajat 5 . Hal ini dikarenakan banyak pasien yang menolak melakukan dialisis dan juga disebabkan adanya perubahan imunitas pada pasien PGK yang semakin memburuk pada derajat lebih lanjut. ${ }^{15}$

Berdasarkan hasil penelitian, dari prevalensi jenis kelamin PGK derajat 4 dan 5 ND didapatkan pasien terbanyak berjenis kelamin perempuan yaitu 71 pasien $(54,19 \%)$ dan 60 pasien berjenis kelamin laki-laki $(43,16 \%)$. Hal ini juga terjadi pada penelitian yang dilakukan Sang et $\mathrm{al}^{16}$ yanng mendapatkan prevalensi perempuan lebih banyak dibanding laki-laki. Hal ini dikarenakan dari total 131 pasien PGK yang dirawat di Poliklinik Ginjal-Hipertensi, pasien yang masuk kriteria inklusi lebih banyak yang berjenis kelamin perempuan dibanding laki-laki yaitu 71 orang.

Berdasarkan hasil penelitian, prevalensi pasien PGK derajat 4 dan 5 ND mayoritas terjadi pada usia 60-69 yaitu sebanyak 58 orang $(44,27 \%)$. Berdasarkan data yang dikumpulkan PERNEFRI (2010), diperkirakan terdapat 70.000 penderita PGK di Indonesia dan salah satu faktor risiko terjadinya penyakit ini ialah penuaan, karena LFG menurun seiring bertambahnya usia. $^{10,17}$ Penurunan LFG menyebabkan semakin sedikit neuron yang berfungsi, termaksuk fungsi dalam produksi hormon eritropoietin. $^{18}$

Berdasarkan hasil penelitian, prevalensi status besi anemia pada PGK derajat 4 dan 5 ND mayoritas memiliki status besi cukup yaitu sebanyak 103 orang $(78,62 \%)$. Hal ini juga terjadi pada penelitian yang dilakukan Baki et al. ${ }^{19}$ Banyak pasien PGK dengan anemia defisiensi besi tidak bisa memroduksi secara adekuat jumlah sel darah merah. Defisiensi besi dapat terjadi karena beberapa penyebab seperti kurangnya asupan makanan yang kaya akan besi, perdarahan, malabsorpsi, atau keganasan gastrointestinal. Feritin merupakan protein yang banyak ditemukan pada makrofag dan hepatosit, serta merupakan cadangan besi dan juga penanda atas jumlah cadangan besi. Menggunakan cadangan besi membutuhkan transferin, yang merupakan transportasi pembawa protein, untuk membawa besi dari sistem retikuloendotelial dan usus ke sum-sum tulang. ${ }^{20}$

Berdasarkan hasil penelitian, pasien dengan PGK yang menjalani terapi transfusi darah yaitu 20 pasien $(15,26 \%)$. Hal ini dikarenakan untuk mencapai kadar hemoglobin preoperatif. Selain itu, kebanyakan pasien yang dirawat di poliklinik Ginjal- 
Hipertensi memilih untuk terapi transfusi darah.

\section{SIMPULAN}

Pada penelitian terhadap pasien dengan PGK periode tahun 2017-2018 di Poliklinik Ginjal-Hipertensi RSUP Prof. Dr. R. D. Kandou didapatkan pasien terbanyak dengan derajat $5 \mathrm{ND}$, jenis kelamin perempuan, rentang usia 60-69 tahun, dengan status besi cukup, dan tidak mendapat terapi transfusi darah.

Penelitian ini bersifat deskriptif dengan pendekatan retrospektif dan mengandalkan data rekam medis, sehingga diperlukan data yang lengkap untuk keakuratan hasil. Oleh karena itu, untuk penelitian selanjutnya kiranya dapat mendapatkan data yang lengkap sehingga dapat mengetahui gambaran anemia dan penanganannya secara klinis, untuk mengatasi atau mengurangi komplikasi PGK.

\section{Konflik Kepentingan}

Penulis menyatakan tidak terdapat konflik kepentingan dalam studi ini.

\section{DAFTAR PUSTAKA}

1. Kidney Disease: Improving Global Outcomes (KDIGO) CKD Work Group. KDIGO 2012 Clinical practice guidline for the evaluation and management of chronic kidney disease. Kidney Int Suppl. 2013;3:1-150.

2. Wish J, Hain D, Marasco R. Anemia of chronic disease in the older patient population selecting the appropriate treament.2011.

3. Word Health Organization. Haemoglobin concentrations for the diagnosis of anemia and assessment of severity. 2011.

4. Between inflamation and bone mineral disorders in chronic kidney disease. International Journal of Recent Scientific Research. 2014;5:1256-6.

5. Universitas Sumatera Utara. Anemia pada penyakit ginjal kronik. [cited 2016 Nov 23]. Available from: http://repository. usu.ac.id/bitstream/123456789/33498/4/ Chapter\%2011.pdf

6. Harper JL. Iron deficiency anemia. 2015 Nov 7. [cited 2016 Sep 11]. Available from: http://reference.medscape.com/refarticle- srch/202333-overview.

7. Suwitra K. Penyakit ginjal kronik. In: Sudoyo A, Setiyohadi B, Alwi I, Simadibrata K M, Setiati S, editors. Buku Ajar Ilmu Penyakit Dalam (6th ed). Jakarta: InternaPublishing, 2014; p. 2159-65.

8. Urrechaga Ea, Borque L, Escanero $J$. Assessing iron status in CKD patients new laboratory parameters. 2012; 10.5772/25645. Available from: www.interchpoen.com

9. Shaheen F, Souqiyyeh MZ, Al-Attar BA, Karkar A, Al Jazrir, Hakami HA, Naguib M. Prevalence of anemia in predialysis chronic kidney disease patients. Saudi J Kidney Dis Transpl. 2011;22(3):456-63

10. Lidsay RM, Burton JA, Edwar N, Dargie HJ, Prentice CRM, Kennedy AC. Dialyzer blood loss. Clin Nephor. 1973;1:29-34.

11. Thomas R, Kanso A, Sedor JR. Chronic Kidney Disease and Its Complications. Prim Care. 2008:35(2): 329-vii

12. Noorazizah.Perbandingan kadar Fe/TIBC dan jumlah eritrosit pada pasien hemodialisa pada pasien PGK. Jurnal UNIMUS. 2010

13. Hidayat R, Azmi S, Pertiwi D. Hubungan kejadian anemia dengan penyakit ginjal kronik pada pasien yang dirawat di Bagian Ilmu Penyakit Dalam RSUP dr M Djamil Padang. Jurnal Kesehatan Andalas. 2016;5(3):546-50.

14. Prodjosudjadi W. Incidence, prevalence, treatment and cost of end-stage renal disease in Indonesia. Ethnicity \& disease. 2006;16(Suppl2):S14-S16.

15. Carrero JJ, Stenvinkel P. Inflammation in end-stage renal disease-what have we learned in 10 years? Semin Dial. 2010; 23:498-509.

16. Sang RR, Park SK, Ji YJ. The prevalence and management of anemia in chronic kidney disease patients: result from the KoreaN Cohort Study for Outcomes in Patients With Chronic Kidney Disease (KNOWCKD). 2017;32(2):249.

17. Tandi M. Hubungan antara derajad penyakit ginjal kronik dengan nilai agregasi trombosit. eBiomedik. 2014;2(2):509-12.

18. Ayu N, Suega K, Widiana G. Hubungan antara beberapa parameter anemia dan laju filtrasi glomerulus pada penyakit ginjal kronik pradialisis. Jurnal Penyakit Dalam. 2010;11:142-4.

19. Baki A, Nevine M, Kamel C. Iron deficiency among anemic pre-dialysis chronic 
66 e-CliniC, Volume 8, Nomor 1, Januari-Juni 2020, hlm. 60-66

kidney patiens. Life Sciense Journal. 2012;9(1):127-132.

20. Taliercio J. Anemia and chronic kidney disease; what's connection?. J Fam Pract. 2010;59(1):14-8 